\title{
Spatial and Temporal Ontogenies of Glutathione Peroxidase and Glutathione Disulfide Reductase During Development of the Prenatal Rat
}

\author{
Hyungsuk Choe, Jason M. Hansen, and Craig Harris \\ Toxicology Program, Department of Environmental Health Science, The University of Michigan, Ann Arbor, MI 48109, USA; \\ E-mail: charris@umich.edu
}

Received 5 January 2001; revised 6 March 2001; accepted 13 March 2001

\begin{abstract}
Spatial and temporal expression and regulation of the antioxidant enzymes, glutathione peroxidase (GSH-Px), glutathione disulfide reductase (GSSG-Rd) may be important in determining cellspecific susceptibility to embryotoxicants. Creation of tissue-specific ontogenies for antioxidant enzyme activities during development is an important first step in understanding regulatory relationships. Early organogenesis-stage embryos were grouped according to the somite number (GD 9-13), and fetuses were evaluated by gestational day (GD 14-21). GSH-Px activities in the visceral yolk sac (VYS) increased on consecutive days from GD 9 to GD 13, representing a 5.7-fold increase during this period of development. GSH-Px activities in VYS decreased after GD 13, ultimately constituting a $37 \%$ decrease at GD 21 . Head, heart, and trunk specific activities generally increased from GD 9 to GD 13 albeit not to the same magnitude as detected in the VYS. GSSG-Rd activities showed substantial increases in the VYS from GD 9 to GD 13, 6.3-fold and decreased thereafter to $50 \%$ by GD 21 . The greatest changes in enzyme activities were noted in the period between GD 10 and GD 11, where the embryo establishes an active cardiovascular system and begins to convert to aerobic metabolism. Generally, from GD 14-21, embryonic organ GSH-Px and GSSG-Rd activities either remained constant or increased as gestation progressed. These studies suggest the importance of the VYS in dealing with ROS and protecting the embryo. Furthermore, understanding the consequences of lower antioxidant activities during organogenesis may help to pinpoint periods of teratogenic susceptibility to xenobiotics and increased oxygen. (c) 2001 John Wiley \& Sons, Inc. J Biochem Mol Toxicol 15:197-206, 2001
\end{abstract}

KEYWORDS: Glutathione Reductase; Glutathione Peroxidase; Visceral Yolk Sac; Organogenesis; Antioxidant; Enzyme Ontogeny; Superoxide Dismutase

Correspondence to: Dr. Craig Harris.

(c) 2001 John Wiley \& Sons, Inc.

\section{INTRODUCTION}

Early experimental evidence indicates that embryos are most susceptible to toxic insult during the period of organogenesis [1]. The mammalian embryo is metabolically active, and as gestation proceeds, the utilization of oxygen increases when aerobic metabolic processes mature to support cellular function [2]. During organogenesis, oxygen requirements for optimal embryonic growth in vitro are shown to be stage specific, increasing from $5 \% \mathrm{O}_{2}$ on gestational day (GD) 9 to $95 \%$ on GD 11. Within this interval the pathways of energy metabolism shifts from predominantly anaerobic glycolysis to aerobic glycolysis, active Krebs cycle function, and oxidative phosphorylation [3-6]. Since these latter processes require $\mathrm{O}_{2}$, embryonic growth is dependent on significantly increasing $\mathrm{O}_{2}$ concentrations [2,7-10]. As embryonic requirements for $\mathrm{O}_{2}$ increases, the probability of reactive oxygen species (ROS) formation also increases, and the cell must adapt, removing ROS and preventing cell damage and death.

Excessive generation of ROS can initiate changes that are detrimental for the cell, namely lipid peroxidation, DNA breakage, protein degradation, and enzyme deactivation [11]. However, a finite amount of ROS is generated during the normal physiological conditions that exist during organogenesis, and its regulation is important for maintaining viability and normal cell function. The generation of ROS is initiated by a single-election reduction of $\mathrm{O}_{2}$ to yield intermediates, which transfer one electron to $\mathrm{O}_{2}$ with the resulting formation of superoxide anion radical $\left(\mathrm{O}_{2}^{-}\right)$. Superoxide anion radical undergoes dismutation to hydrogen peroxide $\left(\mathrm{H}_{2} \mathrm{O}_{2}\right)$ by superoxide dismutase (SOD). Hydrogen peroxide can then be detoxified to water but under conditions where protective measures are overwhelmed, $\mathrm{H}_{2} \mathrm{O}_{2}$ will be converted to the highly reactive hydroxyl radical $(\mathrm{HO} \bullet)$ via the transition metal 
dependent Harber-Weiss reaction [11]. If not removed, the hydroxyl radical can produce structural and functional damage that eventually leads to cell death.

Glutathione (GSH) is the most abundant endogenous intracellular thiol $(0.2-10 \mathrm{mM})$, found in most mammalian and many prokaryotic cells. It is well known for its cellular protective roles against ROS and free radicals by acting as a radical scavenger and intracellular antioxidant $[12,13]$. Glutathione is also known to be an important regulatory element because of its role in maintaining intracellular redox status which, in turn, has been shown to regulate cellular functions including enzyme activities, signal transduction, macromolecular synthesis, cell proliferation, and maintenance of membrane integrity $[13,14]$. Since GSH serves in these capacities in the cell, the regulation of GSH status is of importance in protection against toxicity.

Enzyme pathways exist within the cell to combat the hazardous effects of ROS by acting directly as an antioxidant or regulating GSH status. Molecular oxygen can be converted into ROS via several routes such as, electron leakage in the mitochondria, cellular oxidases (lipoxygenase, cyclooxygenase, xanthine oxidase, etc.), and xenobiotics [11]. The anticonvulsant mephenytoin, the alkylating cancer agent cyclophosphamide, and the keratolytic agent isotretinoin are all known teratogens which are capable of producing oxidative stress as a result of increased production of free radical intermediates and/or subsequent ROS formation. Compounds like paraquat, doxorubicin, and nitrobenzene, which are also teratogens, are detrimental due to their ability to redox cycle [15-20]. Although the superoxide anion can spontaneously form hydrogen peroxide at physio$\operatorname{logical} \mathrm{pH}$, this reaction is rather slow. Superoxide dismutase catalyzed detoxication of superoxide anion to hydrogen peroxide is much more efficient in removing ROS from the cell and is relatively independent of $\mathrm{pH}$. If not removed, hydrogen peroxide can readily cross plasma membranes and can be effectively metabolized by catalase or glutathione peroxidase (GSH-Px) with GSH acting as a cofactor, resulting in glutathione disulphide (GSSG) and water [11].

$$
\mathrm{H}_{2} \mathrm{O}_{2}+2 \mathrm{GSH} \rightarrow \mathrm{GSSG}+2 \mathrm{H}_{2} \mathrm{O}
$$

Moreover, GSH can interact with ROS independent of GSH-Px, becoming oxidized to GSSG and reducing ROS in the process [11].

$$
2 \mathrm{GSH}+2 \mathrm{R} \bullet \rightarrow \mathrm{GSSG}+2 \mathrm{RH}
$$

Whether formed spontaneously or from reactions involving GSH-Px, GSSG can be recycled back to GSH enzymatically via GSSG-Rd using NADPH as the critical cofactor $[11,12,21]$.

$$
\mathrm{GSSG}+\mathrm{NADPH}+\mathrm{H}^{+} \rightarrow 2 \mathrm{GSH}+\mathrm{NADP}^{+}
$$

Control of the GSH/GSSG cycle prevents drastic changes in both GSH and GSSG concentrations and allows for shorter periods of redox imbalance.

Recent advances in our understanding of molecular regulation of gene expression and signal transduction suggest an important role of GSH and redox status. The developmental associations of antioxidant activities and redox status are, therefore, closely linked to cell and tissue differentiation [1,22-24]. During differentiation, cells become increasingly oxidized and changes in antioxidant function include a drop in intracellular GSH content and an increase in GSSG as GSH reacts with ROS $[25,26]$. Given the major role of GSH in maintaining cellular redox balance and the significance of this balance during differentiation, proliferation, and apoptosis, additional oxidative stress caused by chemical exposure could pose a serious threat to the regulation of normal growth and development, and further diminish the capacity of tissues to biotransform xenobiotics [11].

Glutathione peroxidase (GSH-Px) and glutathione disulfide reductase (GSSG-Rd) are directly involved in the regulation of GSH and intracellular redox status. Inherent spatial and temporal variations in GSH-Px and GSSG-Rd specific activities may predispose certain cells or tissues to oxidative damage, redox imbalance, and misregulation of particular intracellular events important during embryonic maturation. Changes in redox status not only predispose the embryo to oxidative stress but are also known to modulate changes in gene expression [26,27 and reviewed in 28,29]. Such differences may be useful in understanding cell and species selectivity of various teratogens.

\section{MATERIALS AND METHODS}

\section{Chemicals}

Sodium azide, $\beta$-NADPH, glutathione, glutathione disulfide, glutathione reductase (Type III: from Bakers Yeast), hydrogen peroxide $\left(\mathrm{H}_{2} \mathrm{O}_{2}\right)$, superoxide dismutase (from Bovine), and epinephrine were all obtained from the Sigma Chemical Company (St. Louis, Mo.). All other chemicals and reagents were of purest grade commercially available.

\section{Animals and Tissue Preparation}

Primagravida Sprague-Dawley rats were timemated and used in all experiments. Day 0 of gestation 
was designated the morning following copulation as indicated by a sperm-positive vaginal smear. Animals were obtained on gestation days 6-9 from the Reproductive Science Program, Small Animal Core, University of Michigan, and maintained on a 12-h light/ 12-h dark cycle until explantation on the designated gestational day. Rats were allowed unrestricted access to food and water.

Developmental stages were categorized by ranges of somite numbers. Range one is somite number 0-12 which represent gestational days GD 9 through GD 10. Range two includes somite numbers 13-20 (GD 10), and range three encompasses somite numbers 21-28 (GD 11). Range four includes embryos of 29 or more somites, corresponding to GD 12. At each specific time point, conceptuses were carefully removed, placed, and washed in warmed Hank's Balanced Salt Solution (HBSS; pH 7.4). One or two embryos and visceral yolk sacs (VYSs) were stored in microcentrifuge tube containing an appropriate buffer. Heads, hearts, and trunks were also dissected from the embryo and placed in a separate tube. Samples were frozen and stored at $-70^{\circ} \mathrm{C}$ until processed for enzyme assay.

For tissues removed at later stages of development, fetuses were dissected free of the uterus and immediately decapitated on ice. One to two litters were sacrificed at each time point of the study. The brain, heart, liver, lung, and kidney were excised and washed with cold HBSS, and then stored in test tubes with appropriate buffers for enzyme assay. Placentae and VYSs were carefully removed prior to collection of other samples, snap-frozen, and stored at $-70^{\circ} \mathrm{C}$ until analysis.

\section{Superoxide Dismutase Assay}

Conceptuses collected in somite ranges one through four were separated into embryos and VYS and were placed in groups (as described earlier) of 2 in $200 \mathrm{~mL}$ of $50 \mathrm{mM}$ Tris- $\mathrm{HCl}$ (pH 7.4). The frozen samples were thawed and sonicated before assay. The SOD assay was performed as originally described by Sun and Zigman [30]. The reaction mixture of $200 \mathrm{mM}$ sodium carbonate/EDTA and $0.3 \mathrm{mM}$ epinephrine (in $0.1 \mathrm{~N} \mathrm{HCl}$ ) were made fresh prior to each assay. One hundred and fifty microliters of sodium carbonate/EDTA and $20 \mu \mathrm{L}$ sample or buffer (for blank) were added to each cuvette and allowed to warm to $30^{\circ} \mathrm{C}$ for $5 \mathrm{~min}$. To activate the reaction, $30 \mu \mathrm{L}$ epinephrine was added to the final mixture in the dark. SOD activity was determined spectrophotometrically with a Beckman BU-650 spectrophotometer by measuring the formation of adrenochrome at $320 \mathrm{~nm}$ at $30^{\circ} \mathrm{C}$ for $10 \mathrm{~min}$. SOD activity was determined by the percent inhibition of the control [30]. One unit of activity was defined as the amount of enzyme producing a $50 \%$ inhibition of the conversion of epinephrine to adrenochrome, measured by change in absorbency. Therefore, higher numbers correlate with less SOD activity as more homogenate is needed to produce a 50\% inhibition. Specific activities were determined as units of activity per milligram protein. Protein was measured using the Bradford assay [31].

\section{Glutathione Peroxidase Assay}

The GSH-Px assay was performed as originally described by Lawrence and Burk [32]. Samples were put in $50 \mathrm{mM}$ potassium phosphate $\left(\mathrm{K}_{2} \mathrm{HPO}_{4}\right.$; $\mathrm{pH}$ 7.0) buffer and were frozen in liquid nitrogen and stored at $-70^{\circ} \mathrm{C}$. At the time of assay, samples were thawed at room temperature, homogenized by ultrasonic tissue disruption and placed on ice. A Beckman BU-650 spectrophotometer was used for this spectrophotometric assay. Each cuvette contained $150 \mu \mathrm{L}$ of reaction mixture with $50 \mathrm{mM}$ potassium phosphate $\left(\mathrm{K}_{2} \mathrm{HPO}_{4} ; \mathrm{pH} 7.0\right)$ solution, $1 \mathrm{mM}$ EDTA, $1 \mathrm{mM} \mathrm{NaN}_{3}$, $2 \mathrm{mM}$ NADPH, and $1 \mathrm{mM} \mathrm{GSH}$. Six microliters of GSSG-Rd (1 E.U./ml) was added at the last step of reaction mixture. Blank cuvettes then received $50 \mu \mathrm{L}$ of $\mathrm{K}_{2} \mathrm{HPO}_{4}$ buffer while sample cuvettes received $50 \mu \mathrm{L}$ of sample. All reactions were gently mixed and incubated at $30^{\circ} \mathrm{C}$ for $4 \mathrm{~min}$. To activate the reaction, $0.25 \mathrm{mM}$ $\mathrm{H}_{2} \mathrm{O}_{2}$ solution was added and mixed into each cuvette. Absorbency was immediately determined at a fixed wavelength of $340 \mathrm{~nm}$ for $4 \mathrm{~min}$. The rate of NADPH oxidation correlates with the oxidation of $\mathrm{H}_{2} \mathrm{O}_{2}$ by GSH-Px. Specific activities were calculated by dividing the rate of oxidation of NADPH $(\mu \mathrm{mol} / \mathrm{min})$ by the milligrams of protein (nmol NADPH oxidized $/ \mathrm{min} / \mathrm{mg}$ protein). Protein was determined by the method of Bradford [31]. Concentrations of NADPH oxidized are calculated from the molar extinction coefficient $(6.22 \times$ $\left.10^{3} \mathrm{M}^{-1} \mathrm{~cm}^{-1}\right)$. A dilution of the sample was performed in order to obtain a linear enzymatic reaction. Each reaction was carried out in duplicate.

\section{Glutathione Reductase Assay}

The GSSG-Rd activity was measured using the method originally described by Carlberg and Mannervik [33]. Samples were placed in $0.2 \mathrm{M} \mathrm{K}_{2} \mathrm{H}$ $\mathrm{PO}_{4} / 2$ mM EDTA (pH 7.0) buffer and frozen at $-70^{\circ} \mathrm{C}$ until analysis. At the time of assay, samples were thawed, homogenized by ultrasonic tissue disruption at room temperature, and immediately placed on ice. The reaction mixture consisted of $100 \mu \mathrm{L}$ of $0.2 \mathrm{M}$ $\mathrm{K}_{2} \mathrm{HPO}_{4} /$ EDTA $(\mathrm{pH} 7.0$ ) solution, $10 \mu \mathrm{L}$ of $2 \mathrm{mM}$ $\mathrm{NADPH} /$ Tris- $\mathrm{HCl}$ solution. All mixtures and solutions 
were prepared at room temperature. Blank cuvettes then received $80 \mu \mathrm{L}$ of deionized water while sample cuvettes received $30 \mu \mathrm{L}$ of deionized water and $50 \mu \mathrm{L}$ of sample. The reaction was initiated by adding and mixing $20 \mathrm{mM}$ GSSG to all the tubes with the final volume of $200 \mu \mathrm{L}$. NADPH oxidation was followed for $4 \mathrm{~min}$ and was recorded using a Beckman BU-650 spectrophotometer. The reduction of GSSG to GSH was determined indirectly by the measurement of the consumption of NADPH, as demonstrated by a decrease in absorbance at $340 \mathrm{~nm}$ as a function of time. Specific activities were calculated by dividing the rate of oxidation of NADPH ( $\mu \mathrm{mol} / \mathrm{min})$ by the milligrams of protein (nmol NADPH oxidized/min/mg protein). Protein content was determined by the method of Bradford [31].

\section{Statistical Analysis}

Fetuses were collected from 8-12 pregnant dams for each time point (GD 9-21). A total of 15-20 embryos/fetuses/tissues $(n)$ isolated from different litters were used for each individual assay. As no more than 2 embryos/fetuses/tissues from any one litter were used for a single assay, each embryo/fetus/tissue represents each individual litter while lessening the number of animals needed for this study. In addition, each embryo/fetus/tissue was assayed in duplicate to a reliable level of reproducibility. For differences between tissues, a one way ANOVA followed by a Tukey's Studentized Range (HSD) was used, where $p$ values $<0.05$ were considered a demonstration of a significant difference.

\section{RESULTS}

\section{Enzyme Activities: Early Organogenesis (GD 9-13)}

\section{Glutathione Peroxidase}

Embryonic GSH-Px activity did not change significantly during the period of development from GD 9 to GD 13 (Figure 1). VYS GSH-Px activity remained constant from GD $9(25.8 \pm 2.75$ nmol NADPH oxidized $/ \mathrm{min} / \mathrm{mg}$ protein) to GD $10(17.4 \pm 1.23 \mathrm{nmol}$ NADPH oxidized $/ \mathrm{min} / \mathrm{mg}$ protein), but then increased significantly on GD 11 by $240 \% \quad(59.2 \pm 3.19 \mathrm{nmol}$ NADPH oxidized/min/mg protein) from GD 10. This trend continued where GSH-Px activity increased by $35 \%$ from GD 11 to GD $12(79.7 \pm 3.61 \mathrm{nmol}$ NADPH oxidized $/ \mathrm{min} / \mathrm{mg}$ protein) and by $21 \%$ from GD 12 to GD $13(96.2 \pm 0.76 \mathrm{nmol}$ NADPH oxidized $/ \mathrm{min} / \mathrm{mg}$ protein).

Regional measurements of GSH-Px activity during early development showed relatively low GSH-Px

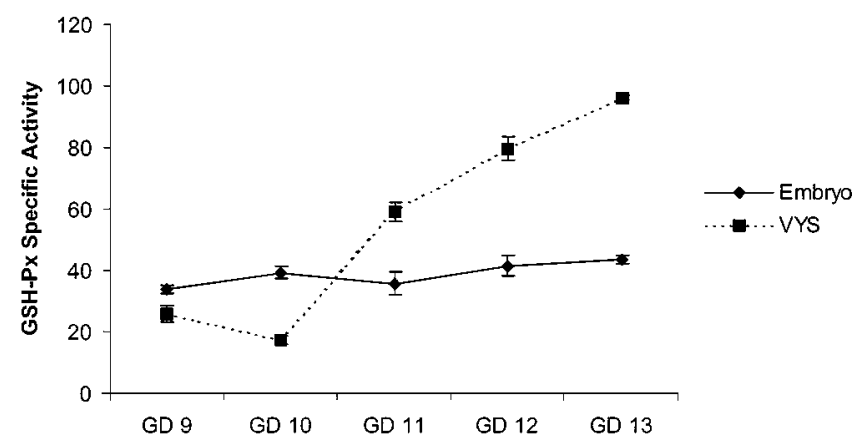

FIGURE 1. Glutathione peroxidase specific activity in early gestation. Embryos were removed and sorted by somite number $(0-12$ $[n=7], 13-20[n=7], 21-28[n=11], 29+[n=11])$ indicating GD 912 , respectively, after which both embryo (solid line) and VYS (dotted line) enzyme activity were determined. GSH-Px Specific activities are expressed as nmol NADPH oxidized/min/mg protein. Data are represented as means \pm SEM.

activities in the head, heart, and trunk, ranging from $3.1 \pm 0.67 \mathrm{nmol} \mathrm{NADPH}$ oxidized $/ \mathrm{min} / \mathrm{mg}$ protein (head) to $5.8 \pm 0.1 .02 \mathrm{nmol}$ NADPH oxidized $/ \mathrm{min} / \mathrm{mg}$ protein (heart; Figure 2). No significant changes in GSH-Px activity was seen on GD 10, but significant increases in GSH-Px activity were detected on GD 11 in all tissues, increasing 8-fold in the head, 4.6-fold in the trunk, and 2.2-fold in the heart. While GSH-Px activities in the head $(28.3 \pm 1.46 \mathrm{nmol} \mathrm{NADPH}$ oxidized $/ \mathrm{min} / \mathrm{mg}$ protein) and trunk $(33.7 \pm 3.24 \mathrm{nmol}$ $\mathrm{NADPH}$ oxidized $/ \mathrm{min} / \mathrm{mg}$ protein) remained relatively constant on GD 12, the heart GSH-Px activity increased to $38.2 \pm 5.17 \mathrm{nmol} \mathrm{NADPH}$ oxidized $/ \mathrm{min} / \mathrm{mg}$ protein, an increase of $172 \%$ from that on GD 11 . GD 13 GSH-Px activities in the head and trunk did not change significantly, but the heart GSH-Px increased by $19 \%$ to $45.4 \pm 1.01 \mathrm{nmol}$ NADPH oxidized/min/mg protein.

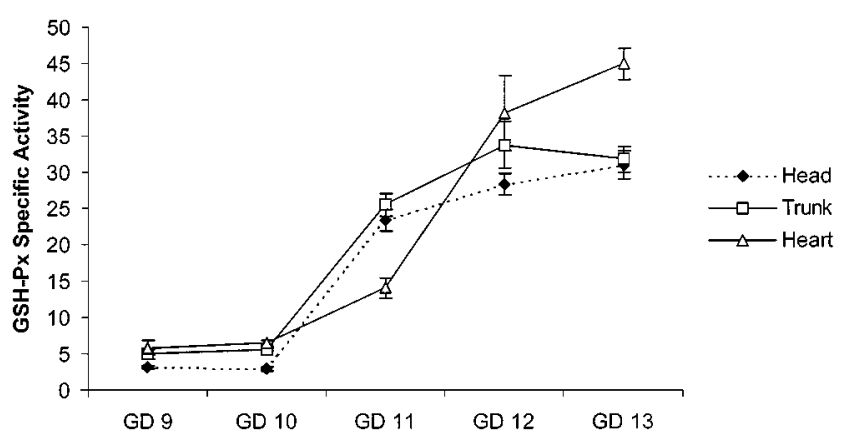

FIGURE 2. Glutathione peroxidase specific activity in head (dotted line diamond), trunk (open squares), and heart (open triangles) from embryos sorted by somite number $(0-12$ [ $n=8], 13-20$ [ $n=9], 21-$ $28[n=17], 29+[n=11])$ indicating GD 9-12, respectively. GSH-Px specific activities are expressed as nmol NADPH oxidized/min/mg protein. Data are represented as means \pm SEM. 


\section{Glutathione Disulfide Reductase}

The GD 9 embryo contained very little GSSG-Rd activity $(12.3 \pm 0.74 \mathrm{nmol}$ NADPH oxidized $/ \mathrm{min} / \mathrm{mg}$ protein) as compared to the GD 9 VYS $(36.4 \pm 4.06 \mathrm{nmol}$ $\mathrm{NADPH}$ oxidized/min/mg protein, Figure 3). Embryonic GSSG-Rd activity on GD 10 did not change significantly $(10.1 \pm 0.69 \mathrm{nmol}$ NADPH oxidized $/ \mathrm{min} / \mathrm{mg}$ protein) but GSSG-Rd activity increased in the VYS by $40 \%$ to $51.0 \pm 2.21 \mathrm{nmol}$ NADPH oxidized $/ \mathrm{min} / \mathrm{mg}$ protein. Embryonic GSSG-Rd activity increased significantly on the following day (GD 11) by $158 \%$ to $26.5 \pm 1.72 \mathrm{nmol} \mathrm{NADPH}$ oxidized/min/mg protein, but did not increase further on the following 2 days of development (GD 12: $26.0 \pm 1.87$ and GD 13: $29.2 \pm 0.65 \mathrm{nmol}$ NADPH oxidized $/ \mathrm{min} / \mathrm{mg}$ protein). While VYS GSSG-Rd activity increased to $63.0 \pm$ $3.50 \mathrm{nmol} \mathrm{NADPH}$ oxidized/min/mg protein, an increase of $24 \%$ from GD 11 , the greatest increase was detected on GD 12 where VYS GSSG-Rd activity increased by $126 \%$ to $124.4 \pm 8.02 \mathrm{nmol} \mathrm{NADPH}$ oxidized/min/mg protein. VYS GSSG-Rd increased even further on GD 13 to $180.3 \pm 6.26 \mathrm{nmol}$ NADPH oxidized $/ \mathrm{min} / \mathrm{mg}$ protein, an increase of $27 \%$.

On GD 9, head $(3.8 \pm 0.45 \mathrm{nmol}$ NADPH oxidized $/ \mathrm{min} / \mathrm{mg}$ protein) and heart $(4.2 \pm 0.46 \mathrm{nmol}$ $\mathrm{NADPH}$ oxidized/min/mg protein) GSSG-Rd activities were not statistically different, but the GSSG$\mathrm{Rd}$ activity of the trunk $(7.5 \pm 0.63 \mathrm{nmol} \mathrm{NADPH}$ oxidized $/ \mathrm{min} / \mathrm{mg}$ protein) showed was significantly more, 97 and $78 \%$ of the head and heart, respectively (Figure 4). GSSG-Rd activities in the head (4.4 \pm $0.52 \mathrm{nmol} \mathrm{NADPH}$ oxidized $/ \mathrm{min} / \mathrm{mg}$ protein) and trunk $(8.0 \pm 0.49 \mathrm{nmol}$ NADPH oxidized $/ \mathrm{min} / \mathrm{mg}$ protein) remained constant on GD 10 but increased signif-

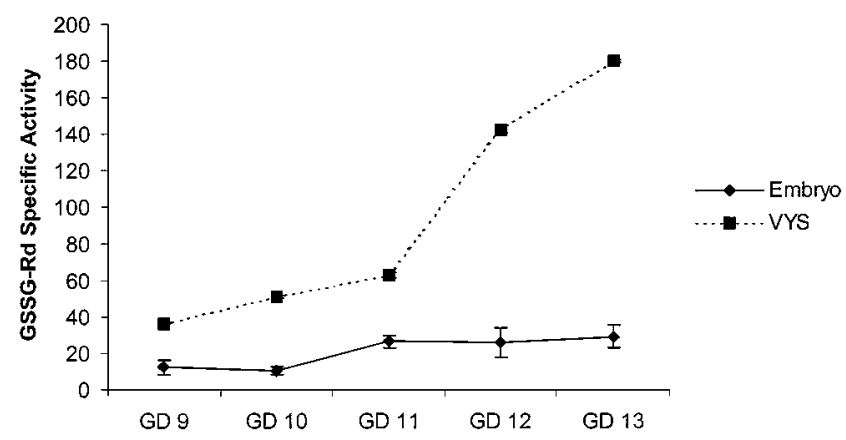

FIGURE 3. Glutathione disulfide reductase specific activity in early gestation. Embryos were removed and sorted by somite number $(0-12$ $[n=6], 13-20[n=8], 21-28[n=13], 29+[n=9])$ indicating GD 9-12, respectively, after which both embryo (solid line) and VYS (dotted line) enzyme activity were determined. GSSG-Rd specific activities are expressed as nmol NADPH oxidized/min/mg protein. Data are represented as means \pm SEM.

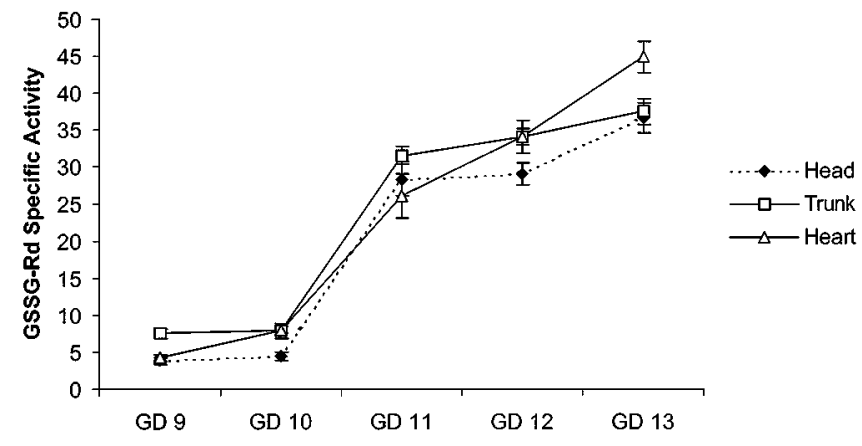

FIGURE 4. Glutathione disulfide reductase specific in head (dotted line diamond), trunk (open squares), and heart (open triangles) from embryos sorted by somite number $(0-12[n=7], 13-20[n=11], 21-$ 28 [ $n=14], 29+[n=14])$ indicating GD 9-12, respectively. GSSG-Rd specific activities are expressed as nmol NADPH oxidized/min/mg protein. Data are represented as means \pm SEM.

icantly in heart to $7.9 \pm 1.03 \mathrm{nmol} \mathrm{NADPH}$ oxidized/ $\mathrm{min} / \mathrm{mg}$ protein, an increase of $88 \%$. The greatest increases in GSSG-Rd activity was detected on GD 11. The head showed the greatest increase (6.5-fold) to $28.4 \pm 2.33 \mathrm{nmol} \mathrm{NADPH}$ oxidized/min/mg protein and was followed by that in the trunk (3.9-fold) to $31.5 \pm 1.20 \mathrm{nmol} \mathrm{NADPH}$ oxidized $/ \mathrm{min} / \mathrm{mg}$ protein. The heart increased by 3.3-fold to $26.1 \pm 2.94$ nmol NADPH oxidized/min/mg protein. GSSG-Rd activities for the head and trunk did not significantly change on either GD 12 or GD 13. However, the heart increased on both GD $12(34.0 \pm 1.17 \mathrm{nmol}$ NADPH oxidized/min/mg protein) by $30 \%$ and GD 13 $(44.9 \pm 2.11 \mathrm{nmol} \mathrm{NADPH}$ oxidized/min/mg protein) by $32 \%$.

\section{Superoxide Dismutase}

Since this is an inhibition assay, lower SOD measurements reflect a greater SOD activity. Early organogenesis-staged (GD 9) embryos had relatively low levels of SOD, $9.6 \pm 0.54$ units $\mathrm{SOD} / \mathrm{mg}$ protein (Figure 5). As development progressed, embryonic SOD activity increased, $7.9 \pm 0.20,3.6 \pm 0.14$, and $3.3 \pm 0.18$ units $\mathrm{SOD} / \mathrm{mg}$ protein for somite ranges 2 through 4 on GD 10, 11, and 12, respectively. The VYS during this same period (GD 9-12) also showed SOD activity changes. The least amount of SOD activity in the VYS was noted at GD 9, 11.2 \pm 1.57 units SOD/mg protein (Figure 5), but SOD increased every subsequent day, $9.2 \pm 0.60$ (GD 10), $4.6 \pm 0.19$ (GD 11), and $4.0 \pm 0.17$ (GD 12) units SOD/mg protein. No significant differences were detected between the embryo and VYS on GD 9, but statistically significant differences between the embryo and VYS were detected on each of the succeeding days, GD 10-GD 12. 


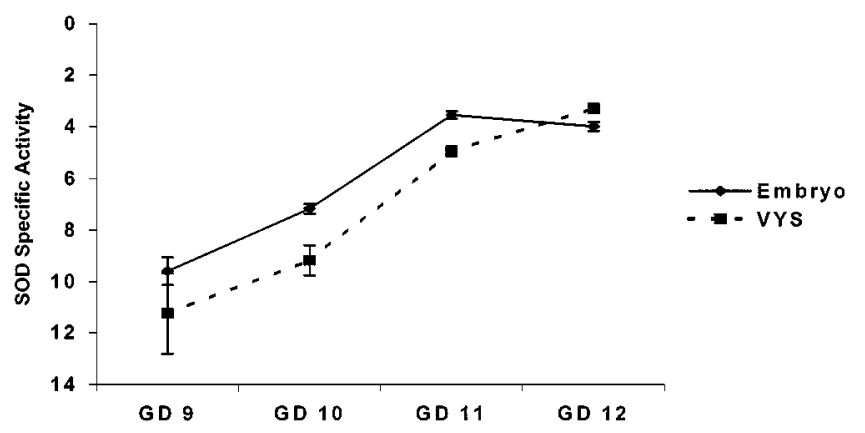

FIGURE 5. Superoxide dismutase specific activity in early gestation. Conceptus were removed and sorted by somite number $(0-12$ $[n=8], 13-20[n=8], 21-28[n=10], 29+[n=9])$ indicating GD 9-12, respectively, after which both embryo (solid line) and VYS (dotted line) enzyme activity were determined. One unit of SOD activity is the amount of enzyme producing a 50\% inhibition of the conversion of epinephrine to adrenochrome. Specific activities are expressed as units of activity per milligram protein. Data are represented as means \pm SEM.

Closer inspection of SOD activities in regions of the embryo on GD 9 showed that the head, trunk, and heart all have relatively equal SOD activity (head: $5.4 \pm 0.70$; trunk: $5.5 \pm 0.08$; heart: $4.0 \pm 1.57$ units $\mathrm{SOD} / \mathrm{mg}$ protein; Figure 6). However, statistically significant differences were detected on the following day (GD 10), where the trunk and heart showed 23\% (5.5 \pm 0.24 units $\mathrm{SOD} / \mathrm{mg}$ protein) and $35 \%$ (4.6 \pm 0.49 units SOD/mg protein) more SOD activity, respectively, than that in the head (7.1 \pm 0.28 units SOD/mg protein). This trend reversed itself in the heart, and SOD activity decreased on GD 11 by $55 \%$ (7.1 \pm 0.68 units SOD/mg protein), which was statistically different from the head $(3.3 \pm 0.41$ units $\mathrm{SOD} / \mathrm{mg}$ protein) and trunk (2.3 \pm 0.14 units $\mathrm{SOD} / \mathrm{mg}$

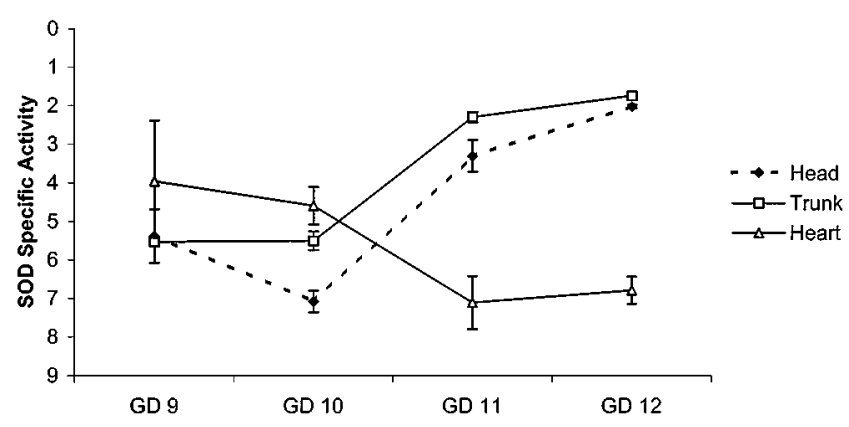

FIGURE 6. Superoxide dismutase specific activity in head (dotted line diamond), trunk (open squares), and heart (open triangles) from embryos sorted by somite number (0-12 [ $n=7], 13-20$ [ $n=9], 21-28$ $[n=11], 29+[n=10])$ indicating GD 9-12, respectively. One unit of SOD activity is the amount of enzyme producing a $50 \%$ inhibition of the conversion of epinephrine to adrenochrome. Specific activities are expressed as units of activity per milligram protein. Data are represented as means \pm SEM. protein) SOD activities on GD 11, which both increased from the preceding day. Head and trunk continued to increase on GD 12 and measured $2.0 \pm 0.05$ and $1.7 \pm 0.04$ units $\mathrm{SOD} / \mathrm{mg}$ protein and were statistically different from the SOD activity of the heart $(6.8 \pm 0.36$ units $\mathrm{SOD} / \mathrm{mg}$ protein).

\section{Enzyme Activities: Late Organogenesis (GD 14-21)}

\section{Glutathione Peroxidase}

Glutathione peroxidase activities of most embryonic tissues did not change during development from GD 14 to GD 21. Rat brain, lung, placenta, and heart GSH-Px activity fluctuated but basically remained constant where changes were not statistically significant (brain: increased 2\%; lung: increased by $37 \%$; placenta: increased by $28 \%$; heart: decreased by $30 \%$; Figure 7). Tissues that did change significantly during this period were the liver (GD 14: $31.4 \pm 1.71 \mathrm{nmol}$ NADPH oxidized/min/mg protein) and the kidney (GD 16: $28.4 \pm 2.25 \mathrm{nmol} \mathrm{NADPH}$ oxidized $/ \mathrm{min} / \mathrm{mg}$ protein), measuring increases in GSH-Px activity by $92 \%$ and $160 \%$ (from GD 14-16 to GD 21), respectively. Interestingly, the kidney did not show any significant changes until the day just prior to birth, nearly doubling from GD $20(33.9 \pm 1.76 \mathrm{nmol} \mathrm{NADPH}$ oxidized $/ \mathrm{min} / \mathrm{mg}$ protein) to GD $21(73.8 \pm 3.50 \mathrm{nmol}$ $\mathrm{NADPH}$ oxidized/min/mg protein). The VYS was the

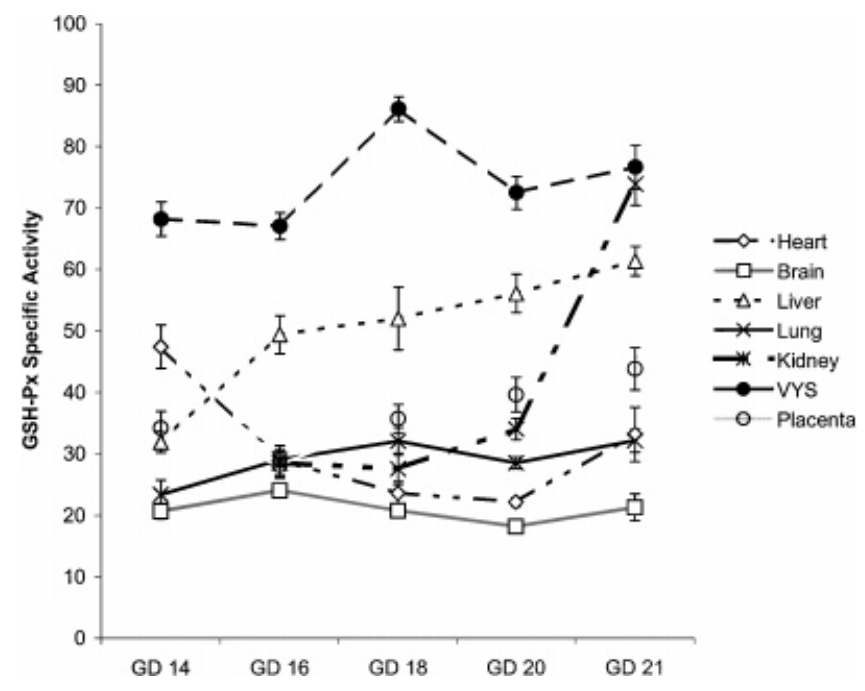

FIGURE 7. Ontogeny of glutathione peroxidase specific activity in late gestation (GD 14 [ $n=7], 16$ [ $n=7], 18[n=11], 20[n=9]$ and 21 $[n=9])$ of the embryonic heart, brain, liver, lung, kidney, VYS, and placenta. GSH-Px specific activities are expressed as nmol NADPH oxidized $/ \mathrm{min} / \mathrm{mg}$ protein. Data are represented as means \pm SEM. 
single tissue that showed constitutively high levels of GSH-Px activity and was statistically different from most other tissues on GD $14(68.2 \pm 2.73 \mathrm{nmol}$ NADPH oxidized $/ \mathrm{min} / \mathrm{mg}$ protein) but did not increase significantly during later phases of development, only increasing slightly by $12 \%(76.5 \pm 3.57 \mathrm{nmol} \mathrm{NADPH}$ oxidized $/ \mathrm{min} / \mathrm{mg}$ protein).

\section{Glutathione Disulfide Reductase}

On GD 14, only one tissue showed considerably higher levels of GSH-Px activity as compared to other tissues and organs, the VYS (Figure 8). The GD 14 VYS showed $172.1 \pm 9.91 \mathrm{nmol}$ NADPH oxidized $/ \mathrm{min} / \mathrm{mg}$ protein, $207 \%$ higher than the next highest tissue, the liver $(56.0 \pm 1.94 \mathrm{nmol}$ NADPH oxidized $/ \mathrm{min} / \mathrm{mg}$ protein). The brain, liver, kidney, and lung all increased during this period of development (GD 14-21), ranging from larger increases of $86 \%$ (liver: GD 14: $56.0 \pm 1.94 \mathrm{nmol} \mathrm{NADPH}$ oxidized $/ \mathrm{min} / \mathrm{mg}$ protein; GD 21: $105.6 \pm 6.70 \mathrm{nmol} \mathrm{NADPH}$ oxidized $/ \mathrm{min} / \mathrm{mg}$ protein) to smaller increases of $16 \%$ (kidney: GD 16 : $55.7 \pm 3.61 \mathrm{nmol} \mathrm{NADPH}$ oxidized/min $/ \mathrm{mg}$ protein; GD 21: $64.7 \pm 6.06 \mathrm{nmol} \mathrm{NADPH}$ oxidized $/ \mathrm{min} / \mathrm{mg}$ protein). No significant changes were detected in heart or the placenta during this time. The only tissue shown to considerably decrease over this period was the VYS, dropping from GD $14(172.1 \pm 9.91 \mathrm{nmol}$ NADPH oxidized/min/mg protein) to GD $21(93.8 \pm 6.15 \mathrm{nmol}$ $\mathrm{NADPH}$ oxidized/min/mg protein) by $45 \%$.

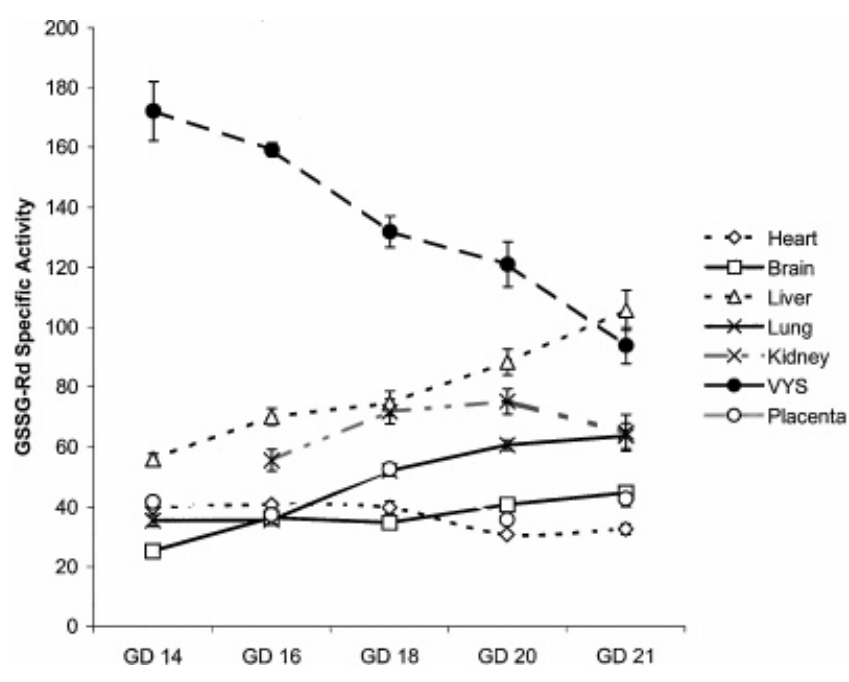

FIGURE 8. Ontogeny of glutathione disulfide reductase specific activity in late gestation (GD $14[n=8], 16[n=7], 18[n=11]$, $20[n=10]$ and $21[n=8])$ of the embryonic heart, brain, liver, lung, kidney, VYS, and placenta. GSSG-Rd specific activities are expressed as nmol NADPH oxidized/min/mg protein. Data are represented as means \pm SEM.

\section{DISCUSSION}

Intracellular redox gradients are believed to play an important role in cellular growth regulation and maturation of cellular function. Metabolically generated oxidants and cellular antioxidant status have been implicated as important factors that direct the initiation of developmental events such as differentiation and proliferation (22-24, 34-36). Because several teratogens are capable of producing oxidative stress and subsequent changes in redox status, the delayed or precocious appearance of antioxidant enzymes such as SOD, GSH-Px, and GSSG-Rd in specific cell types may thus contribute to developmental regulation as well as the differential sensitivity to teratogens and developmental toxicants. The metabolic generation of ROS from dioxygen $\left(\mathrm{HO} \bullet, \mathrm{O} \bullet-{ }_{2}^{-}\right.$and $\mathrm{H}_{2} \mathrm{O}_{2}$ ) require the sequential action of SOD, GSH-Px, and GSSG-Rd for the efficient removal and protection from the potentially damaging oxygen intermediates. The primary aim of the studies described in this report is to evaluate developmental enzyme ontogenies and the relationships between GSH-dependent antioxidant enzymes, GSH-Px and GSSG-Rd. An overall assessment of how the capacity to maintain GSH status and overall redox homeostasis is altered by teratogens will require an understanding of the cellular environments in which these changes take place. Although not directly related to GSH status, a comparison of SOD activities was also included with the early embryonic stages because it was of interest to determine whether changes in GSH-Px activities were correlated with activities of the major enzyme responsible for the generation of its substrate, $\mathrm{H}_{2} \mathrm{O}_{2}$.

During the early developmental periods (GD 9-13), we demonstrated that embryonic GSH-Px and GSSG$\mathrm{Rd}$ activities did not change significantly in the embryo proper, but increase several fold in the VYS. This suggests that the cells of the embryo may not be programmed to respond to the dramatic alterations in oxygen availability and metabolic activity that occurs (GD 10-11) as the heart and vascular systems become functional and the conceptus converts from predominantly anaerobic glycolysis to the citric acid cycle (CAC) and mature mitochondrial functions.

The rodent VYS completely surrounds the developing embryo at this stage of development and has been shown to have considerable metabolic activity as well as capacities for bioactivation and detoxication [15,37]. We have reported that GSH oxidation and GSH-protein mixed disulfide production following xenobiotic insult are consistently greater in the VYS compared with the embryo proper so that the more dramatic increases for GSH-Px and GSSG-Rd over developmental time may reflect the special protective role of the VYS in terms of 
removal of ROS [38]. It is also of interest that the largest increment of increase for GSH-Px activity occurs during a 24-h interval corresponding to the transition from glycolysis to CAC activity and the onset of active circulation. We still do not understand the biochemical and molecular mechanisms that might combine to regulate increased expression of these enzymes, not the mechanisms that regulate their appearance and activities.

Superoxide dismutase activities continue to increase over the early developmental times (GD 9-12) and are not different between the embryo and VYS, nor do they appear to respond to the aforementioned shift in metabolic activity occurring between GD 10 and GD 11. In the embryo, SOD activities plateau and coincide with significant increases in GSH-Px after GD 12. Unlike GSH-Px and GSSG-Rd, SOD activities are not dependent on intermediary metabolism and the production of cofactors such as GSH and NADPH, making it possible for existing SOD activities to adequately convert ever increasing superoxide concentrations to $\mathrm{H}_{2} \mathrm{O}_{2}$ without a regulated increase in expression. The temporal patterns of change and relative differences in activity between tissues we report are in agreement with previously published ontogenies [39-41].

In order to understand whether the cell and tissue specific differences in antioxidant enzyme activities that exist in the embryo could help explain differential sensitivity to teratogens, we began by comparing different tissue segments within the embryo proper. Because removal and assay of specific organs was not practical or possible during the early phases of development, only heads, trunks, and hearts were compared. Relatively few differences in GSH-Px and GSSG-Rd activities were observed between the three tissue segments, again indicating the apparent indifference of the embryo proper in responding to metabolic and environmental changes. Significant increases of activity for both enzymes in the heart on GD 13 are the first signs of selective cell regulation in the embryo. Coincidentally, SOD activities show the opposite reaction in the heart, where activities decline with advancing gestation age. It could be argued that a functional placenta (GD 13) and maturation of SOD activity in other tissues are reducing the commitment of the heart for its own antioxidant protection.

As organs mature and sufficient quantities of tissue are available to facilitate accurate assays (GD 1421), we were able to determine antioxidant enzyme activities in hearts, brains, liver, lung, kidney, VYS, and placenta during the fetal period. Our expectations were that, as organs mature and prepare for the transition to extra-uterine live they will begin to differentially express antioxidant enzymes, resulting in the increase of activities to levels necessary to protect cells from inherent metabolism-dependent ROS formation. In the process, these mature organs will assume a responsibility for the detoxication of ROS initially maintained by the VYS but which is lost with the shedding of the VYS. Nevertheless, until parturition occurs the rat VYS continues to maintain the highest GSH-Px and GSSG$\mathrm{Rd}$ activities. The heart, lung, placenta, and brain show relatively minor changes in activity from GD 14 until term. A study of SOD and GSH-Px expression in mice confirms that these organs show relatively minor changes during the latter half of gestation but demonstrate the dramatic increases that can occur following parturition [39]. The most significant increases in activity occurring during the latter half of gestation appear in the kidney and liver for GSH-Px. A gradual increase in GSH-Px specific activity is observed in the liver during the latter half of the gestation period and is contrasted by a rapid rise of activity in the kidney just prior to parturition at GD 20. Mature kidney and liver both contain the metabolic capacity to produce large amounts of ROS but also develop the capacity to remove it. We are not surprised that activities increase just prior to term when the VYS and other maternal support systems are no longer available to afford protection to the neonate.

Based on the data provided in this report it is unwise to interpret the results in terms of developmental regulation and the related teratogenic responses with out consideration of the various dynamic changes relating to all of the regulatory pathways involved. The innate ability of cells to respond to oxidative stress and restore redox homeostasis is of considerable importance in terms of regulation and cellular protection. Following insult, responses may involve the increased availability of the cofactors GSH and NADPH or may include increased availability of the enzymes themselves. Amicarelli et al. [41] have shown recently that exposure of mouse conceptuses in whole embryo culture to the teratogen phenytoin results in significant alteration in antioxidant activities of GD 14 and GD 19. Phenytoin was shown to significantly increase GSSG-Rd and GSH-Px activities in the GD 14 fetal liver, but were conversely shown to significantly decrease the same activities on GD 19. These results suggest that care be taken not to assume that all responses of a given tissue remain the same over any developmental period. It is not known at this time whether teratogen-induced changes in the intracellular redox status is, in any way, directly related to the cellular modulation of antioxidant enzyme activity. This will remain an open question for further study.

The establishment of enzyme ontogeny profiles is only an approximation to the understanding of differences in organ function and their regulation development. They do, however, provide a more fundamental knowledge regarding the potential relationships between different organs and tissues in terms of 
their relative protective capacitates and reasons why embryonic cells have such different responses to chemical embryotoxicants and teratogens. Disturbances in the intracellular redox balance have been shown to play a major part in the control and regulation of normal developmental events such as proliferation and differentiation [22-24,38,42]. The capacity of cells and tissues to respond to chemical and environmental stresses and restore normal redox homeostasis may determine whether cells continue in a normal course of development or succumb to various stages of toxicity that could result in malformation, functional alterations, or death.

\section{ACKNOWLEDGMENTS}

We give thanks to Surekha Akella and Melissa Beck for their help with rat explantation as well as members of Dr. Loch-Caruso's Reproductive Toxicology lab for their technical assistance.

\section{REFERENCES}

1. Allen RG. Free radicals and differentiation: The interrelationship of development and aging. In: Yu BP, editor. Free Radicals in Aging. Boca Raton, FL: CRC Press; 1993. pp. 11-37.

2. Neubert D, Peters H, Teske S, Kohler E, Barrach HJ. Studies on the problem of "aerobic glycolysis" occurring in mammalian embryos. Naunyn-Schmiedebergs Archiv fur Pharmakologie 1971;268:235-241.

3. New DA, Coppola PT, Cockroft DL. Improved development of head-fold rat embryos in culture resulting from low oxygen and modifications of the culture serum. J Repro Fertil 1976;48:219-222.

4. New DA, Coppola PT. Development of a placental blood circulation in rat embryos in vitro. J Embryol Exp Morphol 1977;37:227-235.

5. New DA. Whole-embryo culture and the study of mammalian embryos during organogenesis. Biologic Rev Cambridge Philos Soc 1978;53:81-122.

6. Sanyal MK, Wiebke EA. Oxygen requirement for in vitro growth and differentiation of the rat conceptus during organogenesis phase of embryo development. Biol Repro 1979;20:639-647.

7. Shepard TH, Tanimura T, Robkin MA. Energy metabolism in early mammalian embryos. Symp Soc Dev Biol 1970;29:42-58.

8. Tanimura T, Shepard TH. Glucose metabolism by rat embryos in vitro. Proc Soc Exp Biol Med 1970;135:51-54.

9. Cox SJ, Gunberg DL. Energy metabolism in isolated rat embryo hearts: effect of metabolic inhibitors. J Embryol Exp Morphol 1972;28:591-599.

10. Cox SJ, Gunberg DL. Metabolite utilization by isolated embryonic rat hearts in vitro. J Embryol Exp Morphol 1972;28:235-245.

11. Fantel AG. Reactive Oxygen Species in Developmental Toxicity: Review and Hypothesis. Teratology 1996;53:196-217.
12. Kosower NS, Kosower EM. The Glutathione Status of Cells. Int Rev Cytol 1978;54:109-160.

13. Meister A, Anderson ME. Glutathione. Ann Rev Biochem 1983;52:711-760.

14. Chandan KS. Nutritional biochemistry of cellular glutathione. Nutr Biochem 1997;8:660-672.

15. Harris C, Namkung MJ, Juchau MR. Regulation of intracellular glutathione in rat embryos and visceral yolk sacs and its effect of 2-nitrosofluorene-induced malformations in the rat whole embryo culture system. Toxicol Appl Pharmacol 1987;88:141-152.

16. Harris C, Kevin L, Stark KL, Juchau MR. Glutathione status and the incidence of neural tube defects elicited by direct acting teratogen in vitro. Teratology, 1988;37:577590.

17. Juchau MR, Fantel AG, Harris C, Beyer BK. The potential role of redox cycling as a mechanism for chemical teratogenesis. Environ Health Perspect 1986;70:131136.

18. Naya M, Mataki Y, Takanira H, Deguchiand T, Yasuda $\mathrm{M}$. Effects of phorone and/or buthionine sulfoximine on teratogenicity of 5-fluorouracil in mice. Teratology 1990;41:275-280.

19. Slott VL, Hales BF. Protection of rat embryos in culture against the embryotoxicity of acrolein using exogenous glutathione. Biochem Pharmacol 1987;36:2187-2194.

20. Wong M, Helston L, Wells PG. Enhancement of murine phenytoin teratogenicity by the gammaglutamylcysteine synthetase inhibitor L-buthionine$(S, R)$-sulfoximine and the glutathione depleter diethyl maleate. Teratology 1989;40:127-141.

21. Jones TW, Thor H, Orrenius S. Cellular defense mechanisms against toxic substance. Arch Toxicol Suppl 1986;9:259-271.

22. Allen RG, Balin A. Oxidative influences on development and differentiation: An overview of a free radical theory of development. Free Rad Biol Med 1989;6:631-661.

23. Sohal RS, Allen RG. Oxidative stress as a causal factor in differentiation and aging. Exp Gerentol 1990;25:499-522.

24. Bravard A, Beaumatin J, Dussaux E, Lesuffleur T, Zweibaum A, Luccioni C. Modifications of the antioxidant metabolism during proliferation and differentiation of colon tumor cell lines. Int J Cancer 1994;59:843-847.

25. Cotgreave IA, Gerdes RG. Recent trends in glutathione biochemisty - glutathione-protein interactions: A molecular link between oxidative stress and cell proliferation. Biochem Biophys Res Comm 1998;242:1-9.

26. Kirlin WG, Cai J, Thompson SA, Diaz D, Kavanagh TJ, and Jones DP. Glutathione redox potential in response to differentiation and enzyme inducers. Free Rad Biol Med 1999;27:1208-1218.

27. Hutter DE, Greene JJ. Influence of the cellular redox state on NF-kappaB-regulated gene expression. J Cell Physiol 2000;183:45-52.

28. Sen CK. Cellular thiols and redox-regulated signal transduction. Cur Top Cell Reg 2000;36:1-30.

29. Arrigo AP. Gene expression and the thiol redox state. Free Rad Biol Med 1999;27:936-944.

30. Sun M, Zigman Z. An improved spectrophotometric assay for superoxide dismutase based on epinephrine autoxidation. Anal Biochem 1978;90:81-89.

31. Bradford MM. A rapid and sensitive method for the quantitation of microgram quantities of protein utilizing the principle of protein-dye-binding. Anal Biochem 1976;72:248-254. 
32. Lawernce A, Burke RF. Glutathione peroxidase activity in selenium-deficient rat liver. Biochem Biophys Res Commun 1976;71:952-958.

33. Carlberg I, Mannervik B. Glutathione Reductase. Meth Enzymol 1985;113:484-490.

34. Burdon RH, Alliangana S, Gill V. Endogeneously generated active oxygen species and cellular glutathione levels in relation of BHK-21 cell proliferation. Free Rad Res 1994;21:121-133.

35. Henney HR, Maxey G. Nutritional control of differentiation (scelotization) of Myxomycetes Physarum flavicomum. Can J Biochem 1975;53:810-818.

36. Hutter DE, Till BG, Greene JJ. Redox state changes in density-dependent regulation of proliferation. Exp Cell Res 1997;232:435-438.

37. Harris C. Glutathione biosynthesis in the postimplantation rat conceptus in vitro. Toxicol Appl Pharmacol 1993;120:2147-2256.

38. Hiranruengchok R, Harris C. Formation of proteinglutathione mixed disulfides in the developing rat con- ceptus following diamide treatment in vitro. Teratology 1995;52:196-204.

39. Di Ilio C, Del Boccio G, Casalone E, Aceto A, Sacchetta P. Activities of enzymes associated with the metabolism of glutathione in fetal rat liver and placenta. Biol Neonate 1986;49:96-101.

40. Tiboni G, Bucciarelli $T$, Amicarelli F, Angelucci S, Iammarrone E, Bellati U, Sacchetta P, Di Ilio C. Spatial distribution of glutathione, glutathione-related and antioxidant enzymes in cultured mouse embryos. Arch Toxicol 1997;72:38-44.

41. Amicarelli F, Tiboni G, Colafarina S, Bonfigli A, Iammarrone E, Miranda M, Di Ilio C. Antioxidant and GSH-related enzyme response to a single teratogenic exposure to the anticonvulsant phenytoin: temporospatial evaluation. Teratology 2000;62:100-107.

42. de Haan JB, Tymms M, Cristiano F, Kola I. Expression of copper/zinc superoxide dismutase and glutathione peroxidase in organs of developing mouse embryos, fetuses, and neonates. Ped Res 1994;35:188-196. 